\title{
Pengukuran Usability Aplikasi Google Classroom Sebagai E-learning Menggunakan USE Questionnaire (Studi Kasus: Prodi Sistem Informasi UNIPMA)
}

\author{
Noordin Asnawi \\ Universitas PGRI Madiun \\ Jurusan Sistem Informasi, Fakultas Teknik, UNIPMA \\ e-mail: noordin_asnawi@unipma.ac.id
}

\begin{abstract}
Abstrak-Google classroom merupakan aplikasi opensource dari Google yang dapat digunakan untuk sistem pembelajaran atau bisa disebut sebagai e-learning. Aplikasi ini termasuk aplikasi yang baru dan masih sedikit yang menggunakannya dalam sistem pembelajaran di sekolah-sekolah maupun di perguruan tinggi, khususnya di program studi Sistem Informasi Fakultas Teknik UNIPMA. Disini aplikasi ini tergolong baru digunakan, maka dalam penelitian ini akan dilakukan pengukuran usability (kebergunaan) untuk mengetahui tingkat kebergunaan dari aplikasi ini. Pengukuran dilakukan dengan menggunakan tool USE Questionnaire dengan menyebar angket kepada responden. Hasil angket dilakukan pengukuran dengan menggunakan skala likert. Dari hasil pengukuran dapat disimpulkan bahwa aplikasi google classroom yang digunakan sebagai e-learning di program studi tersebut memiliki nilai usability yang kurang baik.
\end{abstract}

Kata kunci-Google classroom, usability, USE questionnaire, skala likert

\section{PENDAHULUAN}

Pada era digital saat ini, kebutuhan manusia sebagian besar terpenuhi oleh sistem online. Sangat banyak aplikasi-aplikasi yang dibuat untuk mempermudah pekerjaan maupun kebutuhan manusia, begitupun juga dalam dunia pendidikan. Banyak aplikasi berbentuk online yang dimanfaatkan dalam dunia pendidikan, misalnya web sekolah maupun kampus, sistem informasi akademik, dan lain-lain.

Selain itu terdapat aplikasi online yang digunakan dalam sistem pembelajaran, misalnya dengan membuat aplikasi e-learning. Aplikasi tersebut dapat dibuat sendiri sesuai keinginan dengan bantuan programmer, atau menggunakan layanan e-learning yang telah disediakan oleh beberapa pengembang. Dari beberapa aplikasi e-learning yang ada dan bersifat opensource, aplikasi Google Classroom merupakan aplikasi yang telah digunakan juga sebagai $e$-learning.

Aplikasi ini merupakan layanan gratis dari Google yang dapat digunakan dalam sistem pembelajaran sebagai e-learning. Aplikasi ini termasuk aplikasi yang baru dan masih sedikit yang menggunakannya dalam dunia pendidikan, khususnya di program studi Sistem Informasi UNIPMA. Pada program studi ini mulai menggunakan layanan aplikasi Google Classroom sebagai e-learning. Untuk mengetahui tingkat usability penggunaan aplikasi ini akan dilakukan pengukuran tingkat usability dengan menggunakan bantuan tool USE Questionnaire, dimana tool ini dapat digunakan untuk penyusunan pertanyanpertanyaan dalam kuisioner, sedangkan untuk mencari nilainya digunakan skala likert dengan skala 1 sampai 4.

\section{LANDASAN TEORI}

\subsection{Google Classroom}

Google classroom adalah suatu serambi pembelajaran campuran yang diperuntukkan terhadap setiap ruang lingkup pendidikan yang dimaksudkan untuk menemukanjalan keluar atas kesulitan dalam membuat, membagikan dan menggolong-golongkan setiap penugasan tanpa kertas [1].

Google classroom dianggap sebagai salah satu platform terbaik untuk meningkatkan alur kerja guru. Aplikasi ini menyediakan satu set fitur canggih yang menjadikannya tools yang ideal 
untuk digunakan bersama siswa. Aplikasi ini membantu guru menghemat waktu, menjaga kelas tetap teratur, dan meningkatkan komunikasi dengan siswa. Aplikasi ini tersedia untuk semua orang dengan Google Apps for Education, rangkaian tools produktivitas gratis termasuk Gmail, Drive dan Dokumen [2].

\subsection{Usability}

Ada beberapa definisi mengenai usability, antara lain:

a. Definisi dari ISO

Definisi usability yang paling terkenal adalah dari ISO, International Organization for Standardization (9241-11): “sejauh mana produk dapat digunakan oleh pengguna tertentu untuk mencapai tujuan yang ditentukan dengan efektifitas, efisiensi, dan kepuasan dalam konteks yang ditentukan untuk digunakan" [3].

b. Definisi dari Jakob Nielsen

Mendefinisikan usability sebagai ukuran kualitas pengalaman pengguna ketika berinteraksi dengan produk atau sistem apakah situs web, aplikasi perangkat lunak, teknologi bergerak, maupun peralatanperalatan lain yang dioperasikan oleh pengguna [4].

c. Definisi dari Joseph Dumas dan Janice Redish

Menurut Joseph Dumas dan Janice Redish (1999) usability mengacu kepada bagaimana pengguna bisa mempelajari dan menggunakan produk untuk memperoleh tujuannya dan seberapa puaskah mereka terhadap penggunaannya [5].

Sebuah produk atau layanan dapat memenuhi tingkat usability jika memiliki kriteria antara lain: useful (berguna); efficient (efisien); effective (efektif); satisfying (memuaskan); learnable (mudah dipelajari); dan accessible (mudah diakses).

Dari masing-masing kriteria tersebut dapat dijelaskan seperti berikut ini [6]:

1) Usefulness

Sejauh mana produk memungkinkan pengguna untuk mencapai tujuannya, dan merupakan penilaian terhadap kesediaan pengguna untuk menggunakannya.

2) Efficiency

Merupakan kecepatan dimana tujuan pengguna dapat dicapai secara akurat dan lengkap.

3) Effectiveness

Sejauh mana produk berperilaku seperti pengguna dan kemudahan pengguna untuk menggunakannya sesuai dengan apa yang diinginkan.

4) Learnability

Merupakan bagian dari efektivitas dan berkaitan dengan kemampuan pengguna untuk mengoperasikan sistem.

\section{5) Satisfaction}

Mengacu pada persepsi pengguna, perasaan, dan pendapat pengguna, biasanya diperoleh melalui pertanyaan tertulis dan lisan.

6) Accessibility

Mengacu pada akses terhadap produk yang dibutuhkan untuk mencapai suatu tujuan.

\subsection{USE Questionnaire}

Dalam pengukuran tingkat usability dapat dilakukan dengan menggunakan kuisioner. Kuisioner yang dapat digunakan adalah USE Questionnaire, merupakan tool yang dapat digunakan dalam penyusunan pertanyaanpertanyaan yang akan dibuat dalam bentuk kuisioner.

USE Questionnaire dikembangkan oleh Arnold Lund dan rekan di Ameritech, U.S WEST Advanced Technologies. USE merupakan singkatan dari Usefulness (kegunaan), Satisfction (Kepuasan), dan Ease of use (Kemudahan penggunaan). Pada faktor Ease of use dapat dibagi menjadi 2 faktor, yaitu Ease of Learning (kemudahan belajar) dan Ease of Use (kemudahan penggunaan) [7].

\subsection{Skala likert}

Skala likert digunakan untuk mengukur sikap, pendapat, dan persepsi seseorang atau sekelompok orang tentang kejadian atau gejala sosial. Dalam penelitian gejala sosial, peneliti telah menetapkan secara spesifik skalanya dan selanjutnya disebut variabel penelitian [8]. 
Pada skala likert biasanya digunakan skala pengukuran sebanyak 5 skala. Tetapi dalam penelitian ini menggunakan 4 skala untuk menegaskan pilihan penilaian, supaya tidak ada pilihan jawaban yang berada ditengah-tengah (netral/sedang/cukup).

\section{METODE}

\subsection{Populasi dan Sampel Penelitian}

Populasi berkaitan dengan seluruh kelompok orang, peristiwa, atau benda yang menjadi pusat perhatian penelitian untuk diteliti. Sampel merupakan suatu bagian dari populasi. Hal ini mencakup sejumlah anggota yang dipilih dari populasi $^{[8]}$.

Jumlah responden yang dilibatkan dalam penelitian ini adalah sebanyak 6 responden dari suatu populasi yaitu dosen pada program studi Sistem Informasi Fakultas Teknik Universitas PGRI Madiun.

\subsection{Metode Pengumpulan Data}

Metode pengumpulan data dilakukan dengan metode angket yaitu menyebarkan kuisioner kepada dosen dan mahasiswa. Pengukuran hasil dari angket dilakukan dengan menggunakan skala likert yang terbagi dalam skala 1 sampai 4 yaitu Sangat Tidak Setuju (STS), Tidak Setuju (TS), Setuju (S), dan Sangat Setuju (SS), dengan skor masing-masing skala pada Tabel 1 berikut ini:

Tabel 1. Nilai skala

\begin{tabular}{|l|c|c|c|c|}
\hline Pertanyaan & STS & TS & S & SS \\
\hline Nilai & 1 & 2 & 3 & 4 \\
\hline
\end{tabular}

\subsection{Alur Penelitian}

Pada penelitian yang akan dilakukan, langkahlangkah yang akan dilakukan untuk mencapai tujuan yang diinginkan adalah seperti pada Gambar 1 berikut ini:

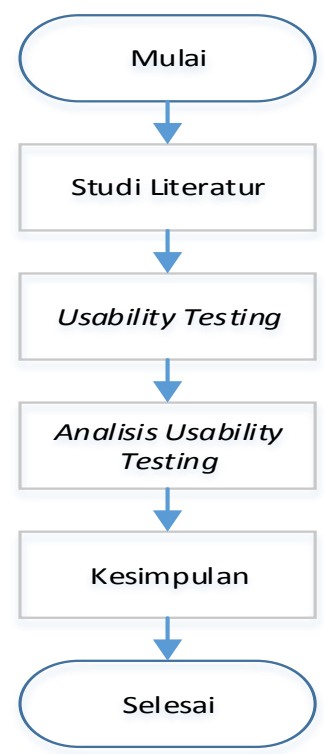

Gambar 1. Alur Penelitian

Keterangan:

Studi literatur : Pencarian referensi mengenai google classrom, usability, USE questionnaire, dan skala likert

Usability testing : penyebaran angket kepada responden

Analisis : perekapan hasil pengisian usability testing angket dan penghitungan nilai usability

Kesimpulan : penarikan kesimpulan hasil dari nilai usability

\section{HASIL}

\subsection{Usability testing}

Langkah awal pada usability testing ini yaitu menyusun pertanyaan-pertanyaan yang akan digunakan untuk angket dan disebarkan ke responden yang telah dipilih dalam suatu populasi di lingkup program studi Sistem Informasi UNIPMA, dimana populasi tersebut ialah dosen. Pertanyaan-pertanyaan ini mengacu pada tool USE questionnaire.

Dari tool tersebut dapat dijadikan pertanyaanpertanyaan dalam kuisioner sebanyak 16 pertanyaan yang terbagi dalam 4 faktor sesuai dengan faktor-faktor pada USE questionnaire yaitu usefulness, satisfaction, ease of use, dan ease of learning. 
Pertanyaan-pertanyaan tersebut dapat dilihat pada Tabel 2 berikut ini:

Tabel 2. Daftar pertanyaan

\begin{tabular}{|c|c|c|c|c|c|c|}
\hline \multirow[b]{2}{*}{ Faktor } & \multirow[b]{2}{*}{ No. } & \multirow[b]{2}{*}{ Pertanyaan } & \multicolumn{4}{|c|}{ Penilaian } \\
\hline & & & $\begin{array}{l}\text { ST } \\
\text { S }\end{array}$ & $\begin{array}{l}\mathbf{T} \\
\mathbf{S}\end{array}$ & $\mathbf{S}$ & $\begin{array}{l}\mathbf{S} \\
\mathbf{S}\end{array}$ \\
\hline \multirow{4}{*}{$\begin{array}{l}\text { Usefuln } \\
\text { ess }\end{array}$} & 1 & $\begin{array}{lr}\text { Aplikasi } & \text { ini } \\
\text { membantu } & \text { anda } \\
\text { menjadi } & \text { lebih } \\
\text { efektif? } & \end{array}$ & & & & \\
\hline & 2 & $\begin{array}{lr}\text { Aplikasi } & \text { ini } \\
\text { membantu } & \text { anda } \\
\text { menjadi } & \text { lebih } \\
\text { produktif? } & \\
\end{array}$ & & & & \\
\hline & 3 & $\begin{array}{l}\text { Apalikasi ini } \\
\text { berguna? }\end{array}$ & & & & \\
\hline & 4 & $\begin{array}{l}\text { Aplikasi ini } \\
\text { dapat } \\
\text { menghemat } \\
\text { waktu saat anda } \\
\text { menggunakanny } \\
\text { a? }\end{array}$ & & & & \\
\hline \multirow{5}{*}{$\begin{array}{c}\text { Ease of } \\
\text { use }\end{array}$} & 5 & $\begin{array}{ll}\text { Aplikasi ini } \\
\text { mudah } \\
\text { digunakan? }\end{array}$ & & & & \\
\hline & 6 & $\begin{array}{l}\text { Aplikasi ini } \\
\text { sederhana untuk } \\
\text { digunakan? }\end{array}$ & & & & \\
\hline & 7 & $\begin{array}{l}\text { Aplikasi ini user } \\
\text { friendly? }\end{array}$ & & & & \\
\hline & 8 & $\begin{array}{l}\text { Anda } \\
\text { menggunakanny } \\
\text { a tanpa instruksi } \\
\text { tertulis? }\end{array}$ & & & & \\
\hline & 9 & $\begin{array}{l}\text { Anda dapat } \\
\text { melakukan } \\
\text { recovery dengan } \\
\text { cepat dan } \\
\text { mudah ketika } \\
\text { membuat } \\
\text { kesalahan? }\end{array}$ & & & & \\
\hline \multirow{2}{*}{$\begin{array}{l}\text { Ease of } \\
\text { learnin } \\
\quad g\end{array}$} & 10 & $\begin{array}{l}\text { Anda } \\
\text { mempelajari } \\
\text { penggunaannya } \\
\text { dengan cepat? }\end{array}$ & & & & \\
\hline & 11 & $\begin{array}{l}\text { Anda mudah } \\
\text { mengingat } \\
\text { bagaimana cara } \\
\text { menggunakanny } \\
\text { a? }\end{array}$ & & & & \\
\hline \multirow{2}{*}{$\begin{array}{l}\text { Satisfa } \\
\text { ction }\end{array}$} & 12 & $\begin{array}{lr}\text { Anda } & \text { puas } \\
\text { dengan } & \text { aplikasi } \\
\text { ini? } & \\
\end{array}$ & & & & \\
\hline & 13 & $\begin{array}{l}\text { Aplikasi ini } \\
\text { menyenangkan } \\
\text { untuk } \\
\text { digunakan? }\end{array}$ & & & & \\
\hline
\end{tabular}

\begin{tabular}{|c|c|c|}
\hline & 14 & $\begin{array}{lr}\text { Cara } & \text { kerja } \\
\text { aplikasi } & \text { ini } \\
\text { sudah } & \text { seperti } \\
\text { yang } & \text { anda } \\
\text { inginkan? } & \\
\end{array}$ \\
\hline & 15 & $\begin{array}{l}\text { Aplikasi ini luar } \\
\text { biasa? }\end{array}$ \\
\hline & 16 & $\begin{array}{l}\text { Aplikasi ini } \\
\text { nyaman untuk } \\
\text { digunakan? }\end{array}$ \\
\hline
\end{tabular}

\subsection{Analisis usability testing}

Setelah dilakukan penyebaran 16 pertanyaan dalam kuisioner kepada 6 responden, maka selanjutnya dilakukan perekapan terhadap hasil kuisioner. Penilaian dilakukan menggunakan skala likert dengan skala 1 sampai 4 yaitu STS (1), TS (2), S (3), dan SS (4).

Hasil rekapan tersebut dapat dilihat pada Tabel 3 berikut ini:

Tabel 3. Hasil rekap penilaian

\begin{tabular}{|c|c|c|c|}
\hline Faktor & No. & Pertanyaan & Penilaian \\
\hline \multirow{4}{*}{$\begin{array}{l}\text { Usefuln } \\
\text { ess }\end{array}$} & 1 & $\begin{array}{l}\text { Aplikasi ini membantu } \\
\text { anda menjadi lebih } \\
\text { efektif? }\end{array}$ & 3,17 \\
\hline & 2 & $\begin{array}{l}\text { Aplikasi ini membantu } \\
\text { anda menjadi lebih } \\
\text { produktif? }\end{array}$ & 3 \\
\hline & 3 & Apalikasi ini berguna? & 3,17 \\
\hline & 4 & $\begin{array}{l}\text { Aplikasi ini dapat } \\
\text { menghemat waktu saat } \\
\text { anda } \\
\text { menggunakannya? }\end{array}$ & 3,17 \\
\hline \multirow{5}{*}{$\begin{array}{c}\text { Ease of } \\
\text { use }\end{array}$} & 5 & $\begin{array}{l}\text { Aplikasi ini mudah } \\
\text { digunakan? }\end{array}$ & 3,17 \\
\hline & 6 & $\begin{array}{l}\text { Aplikasi ini sederhana } \\
\text { untuk digunakan? }\end{array}$ & 3,33 \\
\hline & 7 & $\begin{array}{l}\text { Aplikasi ini user } \\
\text { friendly? }\end{array}$ & 3,17 \\
\hline & 8 & $\begin{array}{l}\text { Anda menggunakannya } \\
\text { tanpa instruksi tertulis? }\end{array}$ & 2,83 \\
\hline & 9 & $\begin{array}{l}\text { Anda dapat melakukan } \\
\text { recovery dengan cepat } \\
\text { dan mudah ketika } \\
\text { membuat kesalahan? }\end{array}$ & 2,17 \\
\hline \multirow{2}{*}{$\begin{array}{l}\text { Ease of } \\
\text { learnin } \\
\quad g\end{array}$} & 10 & $\begin{array}{l}\text { Anda mempelajari } \\
\text { penggunaannya dengan } \\
\text { cepat? }\end{array}$ & 2,67 \\
\hline & 11 & $\begin{array}{l}\text { Anda mudah } \\
\text { mengingat bagaimana } \\
\text { cara menggunakannya? }\end{array}$ & 2,83 \\
\hline $\begin{array}{l}\text { Satisfa } \\
\text { ction }\end{array}$ & 12 & $\begin{array}{l}\text { Anda puas dengan } \\
\text { aplikasi ini? }\end{array}$ & 3 \\
\hline
\end{tabular}




\begin{tabular}{|l|l|l|c|}
\hline & 13 & $\begin{array}{l}\text { Aplikasi ini } \\
\text { menyenangkan untuk } \\
\text { digunakan? }\end{array}$ & 3 \\
\cline { 2 - 4 } & 14 & $\begin{array}{l}\text { Cara kerja aplikasi ini } \\
\text { sudah seperti yang } \\
\text { anda inginkan? }\end{array}$ & 2,67 \\
\cline { 2 - 4 } & 15 & Aplikasi ini luar biasa? & 2,33 \\
\hline 16 & $\begin{array}{l}\text { Aplikasi ini nyaman } \\
\text { untuk digunakan? }\end{array}$ & 3 \\
\hline
\end{tabular}

Tabel 3 menunjukkan nilai dari masing-masing faktor yang terdapat pada USE questionnaire yaitu usefulness, ease of use, ease of learning, dan satisfaction. Pada masing-masing faktor dapat diperoleh nilai rata-rata sebesar: usefulness $=3,13$; ease of use $=2,93$; ease of learning $=2,75$; dan satisfaction $=2,8$.

Jika disesuaikan dengan masing-masing faktor pada USE questionnaire, dapat dikatakan bahwa aplikasi Google Classroom yang digunakan oleh dosen di program studi Sistem Informasi UNIPMA sebagai $e$ learning memiliki nilai yang belum begitu baik. Dari hasil nilai tersebut masing-masing faktor dapat diartikan seperti berikut ini:

a. Nilai faktor usefulness (kegunaan) sebesar 3,13 yang menunjukkan bahwa aplikasi Google Classroom telah memiliki kegunaan yang baik, artinya bahwa aplikasi ini berguna jika digunakan sebagai e-learning.

b. Nilai faktor ease of use (kemudahan penggunaan) sebesar 2,93 yang menunjukkan bahwa aplikasi Google Classroom telah memiliki kemudahan dalam penggunaan yang kurang baik, artinya bahwa aplikasi ini masih ada kesulitan dalam proses penggunaannya.

c. Nilai faktor ease of learning (kemudahan belajar) sebesar 2,75 yang menunjukkan bahwa aplikasi Google Classroom telah memiliki kemudahan dalam belajar yang kurang baik, artinya bahwa aplikasi ini masih ada kesulitan dalam proses belajar menggunakannya.

d. Nilai faktor satisfaction (kepuasan) sebesar 2,8 yang menunjukkan bahwa aplikasi Google Calssroom telah memiliki kepuasan yang kurang baik, artinya bahwa aplikasi ini masih belum memuaskan dalam penggunaanya sebagai $e$ learning. Hal ini juga dipengaruhi oleh faktor ease of use dan ease of learning yang kurang baik yang menyebabkan nilai kepuasan menjadi kurang baik.

\section{KESIMPULAN}

Hasil rekap penilaian usability menggunakan tool USE questionnaire menunjukkan nilai yang baik pada faktor usefulness (kegunaan), sedangkan pada faktor ease of use, ease of learning, dan satisfaction menunjukkan nilai yang kurang baik.

Hal ini dikarenakan faktor ease of use dan ease of learning mempunyai efek pada faktor satisfaction. Jadi jika faktor kemudahan penggunaan dan kemudahan belajar nilainya kurang baik, secara otomatis faktor kepuasan juga menjadi kurang baik. Selain itu, aplikasi ini dapat digunakan sebagai e-learning tetapi membutuhkan waktu untuk mempelajari penggunannya.

\section{DAFTAR PUSTAKA BIBLIOGRAPHY}

[1] "Google Classroom," [Online]. Available: https://id.wikipedia.org/wiki/Google_Classroom. [Diakses 7 Oktober 2017].

[2] S. Iftakhar, "Google Classroom: What Works and How?," Journal of Education and Social Science, vol. III, pp. 12-18, 2016.

[3] C. M. Barnum, Usability Testing Essentials: Ready, Set... Test!, Burlington: Elsevier, 2011.

[4] W. Handiwidjojo dan E. Lussy, "Pengukuran Tingkat Ketergunaan (Usability) Sistem Informasi Keuangan Studi Kasus: Duta Wacana Internal Transaction (Duwit)," JUISI, vol. II, no. 1, pp. 4955, 2016.

[5] D. R. Rahadi, "Pengukuran Usability Sistem Menggunakan Use Questionnaire Pada Aplikasi Android," Jurnal Sistem Informasi (JSI), vol. VI, no. 1, pp. 661-667, 2014.

[6] J. Rubin dan C. Dana, Handbook of Usability Testing, Second Edition: How to Plan, Design, and Conduct Effective Test, Indianapolis: Wiley Publishing, 2008.

[7] A. Lund. [Online]. Available: https://www.researchgate.net/publication/2307867 46_Measuring_Usability_with_the_USE_Question naire. [Diakses 8 Oktober 2017].

[8] S. Guritno, Sudaryono dan U. Rahardja, Theory and Application of IT Research, Yogyakarta: Andi, 2011. 